\title{
KELIMPAHAN NUDIBRANCHIA PADA KARANG BERCABANG DAN KARANG BATU DI PANTAI PANCURAN BELAKANG PULAU KARIMUNJAWA JEPARA
}

\author{
Rizky Chandra Kusuma Ruswahyuni ${ }^{l}$ Subiyanto \\ Program Studi Manajemen Sumberdaya Perairan, Jurusan Perikanan \\ Fakultas Perikanan dan Ilmu Kelautan, Universitas Diponegoro
}

\begin{abstract}
ABSTRAK
Nudibranchia adalah salah satu Moluska tidak bercangkang yang seringkali berwarna terang dan mencolok. Nudibranchia memanfaatkan karang sebagai feeding ground dan spawning ground, tanpa mengganggu kehidupan karang. Tujuan penelitian ini yaitu mengetahui kelimpahan dan perbedaan Nudibranchia yang terdapat pada daerah karang bercabang dan karang batu. Penelitian ini dilaksanakan pada bulan Maret 2013 di Pantai Pancuran Belakang, Pulau Karimunjawa. Metode yang digunakan dalam pengambilan data menggunakan metode line transek sepanjang 50 meter sejajar garis pantai dan kuadran transek dengan ukuran 2 × 2 meter. Hasil penelitian didapatkan Penutupan substrat perairan dimasing-masing lokasi paling banyak tertutupi oleh karang hidup yaitu pada daerah karang bercabang 64,48\% dengan jumlah Nudibranchia sebanyak $38 \mathrm{ind} / 300 \mathrm{~m}^{2}$. Pada daerah karang batu sebesar $75,87 \%$ dengan jumlah Nudibranchia 50 ind $/ 300 \mathrm{~m}^{2}$. Terdapat 5 jenis Nudibranchia di lokasi penelitian yaitu Chromodoris lineolata, Phyllidia varicosa, Phyllidiella nigra, Thuridilla lineolata dan Thuridilla sp. Pada Uji Independent T-Test, rata-rata kelimpahan Nudibranchia pada karang bercabang dan batu adalah sama. Hal ini membuktikan bahwa kelimpahan Nudibranchia sangat dipengaruhi oleh adanya terumbu karang dan tidak berbeda antara karang bercabang (branching) dan karang batu (massive).
\end{abstract}

Kata Kunci: Nudibranchia, Karang Bercabang, Karang Batu, Pantai Pancuran Belakang, Karimunjawa

\author{
Abundance of Nudibranchia at Branching Coral and Massive Coral in The Pancuran Belakang Beach, \\ Karimunjawa Island, Jepara
}

\begin{abstract}
Nudibranch is a one of Mollusca shells often brightly colored and showy. Nudibranch use corals as a feeding ground, spawning ground and live without harming or disturbing the corals. The purpose of this research was to know the abundance and differences of Nudibranch in the corals area both branching and massive coral. The research was conducted on March 2013 in Pancuran Belakang beach, Karimunjawa Island, Jepara. The methods of research was survey method, while colecting data use line transect 50 metres of line and $2 \times 2$ metres of size kuadrant transect where set paralel to the coastline to observe Nudibranchia. The results obshows that the locations was covered by the live coral reef average $64,48 \%$ with 38 ind $/ 300 \mathrm{~m}^{2}$ of Nudibranch while coral massive $75,87 \%$ with the number of Nudibranch abundance $50 \mathrm{ind} / 300 \mathrm{~m}^{2}$. Five Nudibranch were found in this study is Chromodoris lineolata, Phyllidia varicosa, Phyllidiella nigra, Thuridilla lineolata and Thuridilla sp. Based on Independent T-Test, the mean abundance of Nudibranch in massive and branching coral was not differ significantly. Was obviously that the abundance of Nudibranch strongly influenced by the presence of coral reefs and not the type of corals.
\end{abstract}

Key Words: Nudibranchia, Branching Coral, Massive Coral, Pancuran Belakang Beach, Karimunjawa

\footnotetext{
${ }^{1}$ Corresponding author
} 


\section{PENDAHULUAN}

Ekosistem terumbu karang merupakan habitat dari berbagai jenis fauna invertebrata, salah satunya Nudibranchia. Rusaknya terumbu karang yang merupakan habitat Nudibranchia diduga akan mempengaruhi kelimpahan hewan Nudibranchia. Oleh sebab itu, dengan mengamati persentase penutupan jenis karang, kelimpahan individu Nudibranchia dan kondisi perairan, maka dapat dilihat keterkaitan diantara karang, Nudibranchia dan kondisi perairan, sehingga dapat diketahui kelimpahan Nudibranchia. Dengan diketahuinya faktor-faktor yang mendukung kehidupan Nudibranchia, maka diharapkan dapat membantu untuk usaha pelestariannya di masa sekarang dan yang akan datang serta dapat ikut dalam rangka pemeliharaan keseimbangan ekosistem laut.

Menurut English et.al. (1994), bentuk karang Bercabang (branching), memiliki cabang lebih panjang daripada diameter yang dimiliki, banyak terdapat di sepanjang tepi terumbu dan bagian atas lereng terumbu. Bersifat banyak memberikan tempat perlindungan bagi ikan dan invertebrata tertentu. Bentuk karang Batu (massive), dengan ukuran bervariasi serta beberapa bentuk seperti bongkahan batu. Permukaan karang ini halus dan padat, biasanya ditemukan di sepanjang tepi terumbu karang dan bagian atas lereng terumbu.

Menurut Allen dan Steene (1994), Nudibranchia menyebar pada daerah karang. Pada daerah terumbu karang terdapat makanan yang dibutuhkan Nudibranchia. Selain itu karang merupakan tempat menempel bagi veliger larva dari Nudibranchia sebelum melakukan metamorfosis menjadi juvenil. Nudibranchia memanfaatkan karang sebagai feeding ground dan spawning ground, tanpa merugikan atau mengganggu kehidupan karang.

Penelitian ini bertujuan untuk mengetahui kelimpahan Nudibranchia yang terdapat pada daerah karang bercabang dan karang batu serta mengetahui perbedaan kelimpahan Nudibranchia pada karang bercabang maupun karang batu. Penelitian ini dilaksanakan pada bulan Maret 2013 di Perairan Pantai Pancuran Belakang, Pulau Karimunjawa, Jepara.

\section{MATERI DAN METODE Materi}

Materi yang digunakan dalam penelitian ini adalah Nudibranchia yang terdapat di rataan terumbu karang pada daerah karang bercabang dan daerah karang batu. Peralatan yang digunakan dalam penelitian ini yaitu line transek, kuadran transek, GPS, masker, snorkel, rol meter, thermometer, refraktometer, stopwatch, bola arus, kamera bawah air, sabak dan alat tulis.

\section{Metode}

Metode yang digunakan dalam penelitian ini adalah metode observasi, dimana metode yang dilakukan dengan pengamatan dan pencatatan secara sistematis baik langsung maupun tidak langsung mengenai kejadian-kejadian yang sedang diselidiki (Hadi, 1980). Pada pengambilan data kelimpahan Nudibranchia menggunakan metode kuadran transek yang berukuran 2 x 2 meter. Metode yang digunakan dalam pengambilan data prosentase penutupan karang dengan menggunakan metode line transek. Pengamatan ini dilakukan pada daerah karang bercabang dan daerah karang batu. Penelitian ini dilakukan dengan peletakan 3 line dan kuadran transek pada masing-masing lokasi, lokasi A yaitu daerah karang bercabang dan lokasi $\mathrm{B}$ yaitu daerah karang batu. Jarak antar line transek yaitu 5 meter. Line transek dibentangkan sepanjang 50 meter sejajar dengan garis pantai.

\section{Analisis Data}

Persentase karang hidup, karang mati, pasir dan pecahan karang, dihitung dengan menggunakan rumus (Samingan, 1993) :

Dimana:

$$
C=\frac{C i}{L} \times 100 \%
$$

C : Persentase tutupan karang

$\mathrm{Li}$ : Panjang tutupan karang jenis ke-i (cm)

L : Panjang total transek $(\mathrm{cm})$

Kriteria Persen Penutupan Terumbu Karang Menurut Keputusan Menteri Lingkungan Hidup No. 4 Tahun 2001 adalah sebagai berikut :

$\begin{array}{ll}\text { Buruk } & =0-24,9 \% \\ \text { Sedang } & =25-49,9 \% \\ \text { Baik } & =50-74,9 \% \\ \text { Baik Sekali } & =75-100 \%\end{array}$


Kelimpahan dari Nudibranchia dihitung dengan menggunakan rumus dalam Samingan (1993) :

Dimana:

$$
K R=\frac{N i}{N} \times 100 \%
$$

KR : Kerapatan Relatif

$\mathrm{Ni}$ : Jumlah individu jenis ke-i

$\mathrm{N}$ : Jumlah total individu

Untuk menentukan indeks keanekaragaman, dihitung dengan menggunakan formula ShannonWieaner (Samingan, 1993) :

$$
H^{\prime}=-\sum_{i=1}^{i} P i \ln P i
$$

Menghitung keseragaman jenis dapat dihitung menggunakan rumus Evennes (Samingan, 1993), yaitu:

Dimana:

$$
E=\frac{H^{\prime}}{H \max }
$$

H' : Indeks Keanekaragaman Jenis

$\mathrm{Pi} \quad: \mathrm{Ni} / \mathrm{N}$

E : Indeks keseragaman

$\mathrm{H}$ max : Keanekaragaman spesies maksimum $(\ln \mathrm{S})$

$\mathrm{S} \quad$ : Jumlah genus penyusun komunitas

Tabel 1. Kriteria penilaian kualitas lingkungan (Wibisono, 2005)

\begin{tabular}{lll}
\hline No. & \multicolumn{1}{c}{$\mathrm{H}^{\prime}$} & Struktur Komunitas \\
\hline 1. & $>2,41$ & Sangat stabil \\
2. & $1,81-2,4$ & Lebih stabil \\
3. & $1,21-1,8$ & Stabil \\
4. & $0,61-1,2$ & Cukup stabil \\
5. & $<0,6$ & Tidak stabil \\
\hline
\end{tabular}

Hipotesis digunakan untuk menduga ada tidaknya perbedaan kelimpahan Nudibranchia pada daerah karang bercabang dan karang batu di Pantai Pancuran Belakang, Pulau Karimunjawa. Hipotesis yang digunakan dalam penelitian ini adalah Hubungan kelimpahan Nudibranchia pada tutupan terumbu karang. Ho = Tidak ada perbedaan kelimpahan Nudibranchia pada karang bercabang dan batu $\mathrm{H}_{1}=$ Ada perbedaan kelimpahan Nudibranchia pada karang bercabang dan batu

Probabilitas

Kaidah pengambilan keputusan adalah sebagai berikut :

$=P$ value $\leq\left(\propto=0,05\right.$, maka terima $\mathrm{H}_{1}$ tolak $\left.\mathrm{H}_{0}\right)$

$=P$ value $>\left(\propto=0,05\right.$, maka terima $\mathrm{H}_{0}$ tolak $\left.\mathrm{H}_{1}\right)$

\section{HASIL DAN PEMBAHASAN}

\section{Gambaran Umum Lokasi Penelitian}

Kepulauan Karimunjawa merupakan gugusan kepulauan berjumlah 27 pulau yang terletak di Laut Jawa. Secara administratif masuk kedalam wilayah Kecamatan Karimunjawa, Kabupaten Jepara, Jawa Tengah. Secara Geografis Taman Nasional Karimunjawa terletak antara $5^{0} 40^{\prime} 39^{\prime \prime}-5^{0} 55^{\prime} 00^{\prime \prime}$ LS dan $110^{\circ} 05^{\prime} 57^{\prime \prime}-110^{\circ} 31$ ' $15^{\prime \prime}$ BT dengan luas 111.625 Ha meliputi 22 pulau. Perairan pantai Pancuran Belakang termasuk dalam Desa Kapuran, Taman Nasional Karimunjawa. Letak geografis pantai Pancuran Belakang pada lokasi sampling A (daerah karang bercabang) $5^{\circ} 53^{\prime} 13^{\prime \prime} \mathrm{LS}$ dan $110^{\circ} 26^{\prime} 56^{\prime \prime} \mathrm{BT}$, pada lokasi sampling B (daerah karang batu) $5^{\circ} 53^{\prime} 12^{\prime \prime} \mathrm{LS}$ dan $110^{\circ} 26^{\prime} 58^{\prime \prime}$ BT. Pantai Pancuran Belakang terdapat di bagian sebelah timur dalam Pulau Karimunjawa. Lokasi ini bernama Pancuran Belakang karena terdapat mata air yang berada tidak jauh dari pantai. 


\section{Hasil}

\section{Tutupan Terumbu Karang Pada Lokasi Penelitian}

Berikut merupakan hasil dari panjang dan persentase tutupan substrat perairan di lokasi penelitian:

Tabel 2. Panjang tutupan dan persentase tutupan substrat perairan pada lokasi penelitian

\begin{tabular}{lcccc}
\hline \multirow{2}{*}{ Jenis Penutupan } & \multicolumn{2}{c}{ Panjang Tutupan $(\mathrm{cm})$} & \multicolumn{2}{c}{ Persentase Tutupan $(\%)$} \\
\cline { 2 - 5 } & Lokasi A & Lokasi B & Lokasi A & Lokasi B \\
\hline Karang Hidup & 9672 & 11380 & 64,48 & 75,87 \\
Karang Mati & 1658 & 1070 & 11,05 & 7,13 \\
Pecahan Karang & 1861 & 990 & 12,41 & 6,60 \\
Pasir & 1695 & 1285 & 11,3 & 8,57 \\
Alga & 114 & 275 & 0,76 & 1,83 \\
\hline Jumlah & 15000 & 15000 & 100 & 100 \\
\hline
\end{tabular}

Penutupan substrat perairan berupa karang hidup didaerah karang batu merupakan penutupan terbesar yaitu $75,87 \%$ dengan panjang tutupan $11380 \mathrm{~cm}$. Nilai terkecil pada penutupan alga yaitu $0,76 \%$ dengan panjang tutupan $114 \mathrm{~cm}$.

Hasil penelitian panjang tutupan dan persentase tutupan karang hidup pada lokasi penelitian tersaji pada tabel berikut:

Tabel 3. Panjang dan persentase tutupan karang hidup pada lokasi penelitian

\begin{tabular}{lcccc}
\hline \multirow{2}{*}{ Genus Karang } & \multicolumn{2}{c}{ Panjang Tutupan } & \multicolumn{2}{c}{ Persentase Tutupan } \\
\cline { 2 - 5 } Bercabang & Lokasi A & Lokasi B & Lokasi A & Lokasi B \\
Acropora & 4365 & 1945 & 29,1 & 12,97 \\
Milepora & 640 & 170 & 4,27 & 1,13 \\
Hydnopora & 692 & 390 & 4,62 & 2,6 \\
Stylopora & 605 & 590 & 4,03 & 3,93 \\
Pocilopora & 90 & 40 & 0,6 & 0,28 \\
Montipora & 263 & 90 & 1,75 & 0,6 \\
Batu & & & & \\
Porites & 1007 & 1395 & 6,71 & 9,3 \\
Fungia & 128 & 200 & 0,85 & 1,33 \\
Coeloceris & 513 & 830 & 3,42 & 5,53 \\
Goniastrea & 281 & 830 & 1,87 & 5,53 \\
Pavona & 185 & 480 & 1,23 & 3,2 \\
Favia & 208 & 600 & 1,39 & 4 \\
Merulina & 120 & 590 & 0,8 & 3,93 \\
Goniopora & 225 & 850 & 1,5 & 5,67 \\
Cypastrea & 215 & 570 & 1,43 & 3,8 \\
Heliopora & 135 & 520 & 0,9 & 3,47 \\
Euphyllia & - & 180 & - & 1,2 \\
Favites & - & 510 & - & 3,4 \\
Turbinaria & - & 600 & - & 4 \\
\hline & & & & \\
\hline
\end{tabular}

Berdasarkan tabel diatas, pada genus karang Acropora memiliki panjang tutupan dan persentase tutupan terbesar yaitu masing-masing $4365 \mathrm{~cm}$ dan 29,1\%. Panjang dan persentase tutupan terkecil pada genus karang Pocillopora yaitu masing-masing sebesar $40 \mathrm{~cm}$ dan 0,28\%.

Tabel 4. Jumlah Nudibranchia pada substrat karang hidup

\begin{tabular}{llcccc}
\hline \multirow{2}{*}{ No. } & \multirow{2}{*}{ Jenis } & \multicolumn{3}{c}{ Jumlah Nudibranchia pada substrat karang hidup } \\
\cline { 3 - 6 } & & \multicolumn{2}{c}{ Lokasi A } & \multicolumn{2}{c}{ Lokasi B } \\
\cline { 3 - 6 } & & Bercabang & Batu & Bercabang & Batu \\
\hline 1 & Chromodoris lineolata & 0 & 3 & 0 & 7 \\
2 & Phyllidia varicose & 1 & 0 & 1 & 1 \\
3 & Phyllidiella nigra & 4 & 0 & 1 & 0 \\
4 & Thuridilla lineolata & 1 & 3 & 3 & 5 \\
5 & Thuridilla sp & 7 & 10 & 6 & 1 \\
\hline & Jumlah & & 3 & 1 & 14 \\
\hline
\end{tabular}

Jumlah Nudibranchia pada substrat karang hidup terbesar pada jenis Chromodoris lineolata yaitu 7 pada lokasi karang batu. Terdapat 14 Nudibranchia di jenis karang massive dan yang terkecil terdapat di jenis karang branching yaitu 6 Nudibranchia. 
http://ejournal-sl.undip.ac.id/index.php/maquares

Tabel 5. Kelimpahan Nudibranchia pada lokasi penelitian (ind/300 $\left.\mathrm{m}^{2}\right)$

\begin{tabular}{llcccc}
\hline \multirow{2}{*}{ No. } & \multirow{2}{*}{ Jenis } & \multicolumn{4}{c}{ Kelimpahan Nudibranchia } \\
\cline { 2 - 6 } & & KI & KR $(\%)$ & KI & KR (\%) \\
\hline & & 8 & 21,05 & 14 & 28 \\
\hline 1. & Chromodoris lineolata & - & - & 9 & 18 \\
2. & Phyllidia varicose & 7 & 18,42 & 11 & 22 \\
3. & Phyllidiella nigra & 16 & 42,11 & 9 & 18 \\
4. & Thuridilla lineolata & 7 & 18,42 & 7 & 14 \\
5. & Thuridilla sp & 38 & $100 \%$ & 50 & $100 \%$ \\
\hline & Jumlah & & & & \\
\hline
\end{tabular}

Berdasarkan tabel 5, kelimpahan relatif terbesar pada jenis Thuridilla lineolata yaitu 42,11\% dan yang terkecil yaitu Thuridilla sp. $14 \%$.

Tabel 6. Kelimpahan total Nudibranchia pada lokasi penelitian (ind/600 $\mathrm{m}^{2}$ )

\begin{tabular}{llcccc}
\hline \multirow{2}{*}{ No. } & Jenis & \multicolumn{3}{c}{ Jenis Penutupan Karang } & \multirow{2}{*}{$\begin{array}{c}\text { Total Kelimpahan } \\
\text { (ind/600m }\end{array}$} \\
\cline { 3 - 5 } & & KH & KM & PK & \\
\hline 1 & Chromodoris lineolata & 11 & 11 & 0 & 22 \\
2 & Phyllidia varicose & 2 & 7 & 0 & 9 \\
3 & Phyllidiella nigra & 2 & 5 & 11 & 18 \\
4 & Thuridilla lineolata & 16 & 5 & 4 & 25 \\
5 & Thuridilla sp & 6 & 8 & 0 & 14 \\
\hline & Jumlah & 37 & 36 & 15 & 88 \\
\hline
\end{tabular}

Keterangan: KH: Karang Hidup; KM: Karang Mati; PK: Pecahan Karang

Adapun histogram kelimpahan total dari Nudibranchia yang terdapat pada sustrat di rataan terumbu karang adalah sebagai berikut:

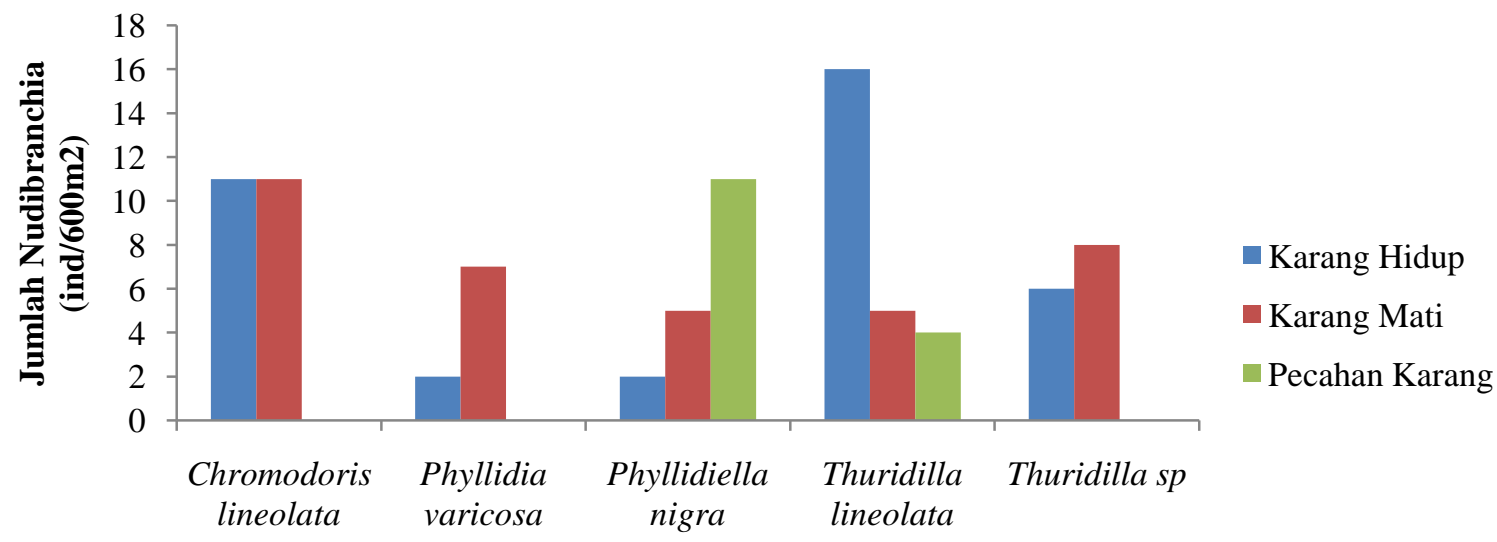

Jenis Nudibranchia

Gambar 1. Histogram kelimpahan total Nudibranchia

Berdasarkan histogram diatas, nilai terbesar pada jenis Thuridilla lineolata pada substrat karang hidup dan paling rendah pada substrat pecahan karang hingga tidak ada Nudibranchia.

\section{Keanekaragaman (H') dan Keseragaman (e) Terumbu Karang}

Hasil perhitungan nilai indeks keanekaragaman, keseragaman dan dominansi terumbu karang tersaji pada tabel sebagai berikut:

Tabel 7. Indeks keanekaragaman, keseragaman terumbu karang pada daerah karang bercabang dan daerah karang batu

\begin{tabular}{llll}
\hline No. & \multicolumn{1}{c}{ Lokasi } & $\mathrm{H}^{\prime}$ & $\mathrm{E}$ \\
\hline 1 & Karang Bercabang & 2,475 & 0,893 \\
2 & Karang Batu & 2,4745 & 0,840 \\
\hline
\end{tabular}




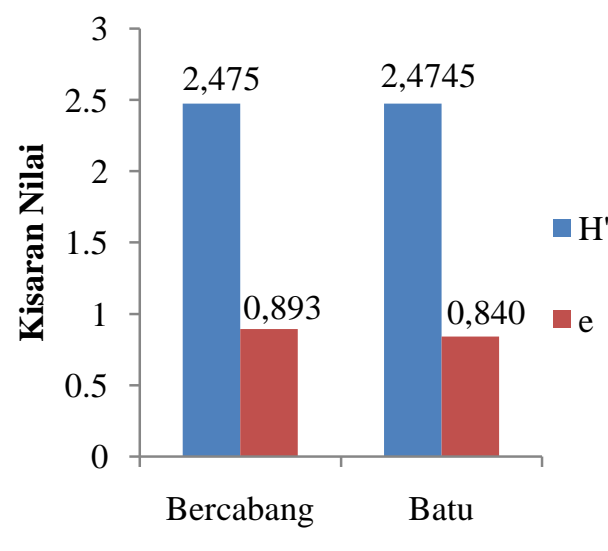

Lokasi Penelitian

Gambar 2. Histogram Indeks Keanekaragaman dan indeks Keseragaman Karang pada Lokasi Penelitian

Nilai indeks keanekaragaman pada daerah karang bercabang dan karang batu tidak terlalu menunjukkan perbedaan yang besar, begitu halnya dengan indeks keseragaman yang nilainya hampir sama. Indeks keseragaman mendekati angka 1 yang berarti dalam komunitas tersebut tidak didominansi oleh satu spesies. Hal ini menunjukkan bahwa ekosistem dalam kondisi relatif baik.

\section{Keanekaragaman (H') dan Keseragaman (E) Nudibranchia}

Tabel 8. Indeks Keanekaragaman dan keseragaman Nudibranchia di Daerah Karang Bercabang dan Karang Batu

\begin{tabular}{llll}
\hline No. & Lokasi & H' $^{\prime}$ & E \\
\hline 1 & Karang Bercabang & 1,3154 & 0,949 \\
2 & Karang Batu & 1,5822 & 0,983 \\
\hline
\end{tabular}

Nilai indeks keanekaragaman Nudibranchia pada daerah karang bercabang yaitu 1,3154 dan pada daerah karang batu sebesar 1,5822. Nilai indeks keseragaman pada kedua lokasi tidak menunjukkan perbedaan yang terlalu besar yaitu masing-masing bernilai 0,949 dan 0,983.

\section{Parameter Perairan}

Tabel 9. Parameter perairan pada daerah karang bercabang dan karang batu

\begin{tabular}{|c|c|c|c|c|}
\hline \multirow{2}{*}{ No. } & \multirow{2}{*}{ Parameter } & \multicolumn{2}{|c|}{ Kisaran Hasil } & \multirow{2}{*}{ Tinjauan Pustaka } \\
\hline & & Karang Bercabang & Karang Batu & \\
\hline 1 & Suhu $\left({ }^{\circ} \mathrm{C}\right)$ & $29-32$ & $29-32$ & (Sukarno, 1995) \\
\hline 2 & Kecerahan (m) & Sampai dasar & Sampai Dasar & (Sukarno, 1995) \\
\hline 3 & Salinitas $(\% / 00)$ & $30-31$ & $31-34$ & (Nybakken, 1992) \\
\hline 4 & $\mathrm{pH}$ & 8 & 8 & $6,5-8,5 \quad($ Supriharyono, 2007) \\
\hline 5 & Kec. Arus $(\mathrm{m} / \mathrm{s})$ & $0,05-0,06$ & $0,05-0,07$ & (Dahuri et al, 2001) \\
\hline 6 & Kedalaman (m) & $1,75-3$ & $2-3$ & (Nybakken, 1992) \\
\hline 7 & Substrat & \multicolumn{2}{|c|}{$\begin{array}{l}\text { Karang hidup, Pecahan karang, Karang } \\
\text { mati, Pasir, Rumput laut }\end{array}$} & $\begin{array}{l}\text { Karang hidup, Pecahan karang, } \\
\text { Karang mati, Pasir }\end{array}$ \\
\hline
\end{tabular}

\section{Pembahasan}

Karang bercabang yang ditemukan dari hasil penelitian berdasarkan tabel 2 adalah genus Acropora, Stylophora, Pocillopora, Hydnopora, Milepora, Montipora. Karang batu yang ditemukan yaitu genus Porites, Fungia, Coeloceris, Goniastrea, Pavona, Merulina, Goniopora, Turbinaria, Favites, Favia, Cypastrea, Heliopora, Euphyllia. Daerah karang bercabang merupakan daerah yang memiliki banyak jenis karang bercabang, meskipun terdapat juga beberapa jenis karang berbentuk batu. Karang bercabang memiliki pertumbuhan yang lebih cepat daripada karang batu, dengan pertumbuhan bisa mencapai $20 \mathrm{~cm} / \mathrm{tahun}$ dan pada karang batu pertumbuhan mencapai kurang lebih $1 \mathrm{~cm} /$ tahun. Karang bercabang dan batu bersifat banyak memberikan perlindungan bagi ikan dan invertebrata air (Supriharyono, 2007). 
Persentase penutupan substrat perairan pada daerah karang bercabang (lokasi A), karang hidup sebesar $64,48 \%$, karang mati $11,05 \%$, pecahan karang $12,41 \%$, pasir $11,03 \%$ dan alga $0,76 \%$. Pada lokasi karang batu (lokasi B), persentase karang hidup sebesar 75,87\%. Menurut Keputusan Menteri Lingkungan Hidup No.4 Tahun 2001, persen tutupan terumbu karang hidup dengan kisaran antara 50-74,9\% termasuk dalam kategori baik dan kisaran antara 75-100\% termasuk dalam kategori baik sekali.

Persentase penutupan karang hidup tertinggi pada daerah karang bercabang yaitu genus Acropora $29,1 \%$ dan Porites $6,71 \%$, serta untuk penutupan karang hidup terendah yaitu pada genus karang Pocillopora $0,6 \%$, dan Merulina $0,8 \%$. Pada daerah karang batu, persentase penutupan karang hidup tertinggi pada genus karang Acropora dan Porites yang masing-masing bernilai 12,97\% dan 9,3\%, sedangkan penutupan karang hidup terendah yaitu genus Pocillopora $0,28 \%$ dan Milepora 1,13\%. Pada lokasi penelitian, daerah rataan terumbu karang banyak terdapat karang bentuk Acropora. Menurut Azhar dan Edinger (1996), Pada daerah rataan terumbu banyak ditemukan jenis karang seperti Acropora dan Porites yang mendominansi persentase penutupan karang di rataan terumbu.

\section{Kelimpahan Nudibranchia}

Pada daerah rataan terumbu karang, Lokasi A ditemukan 4 jenis Nudibranchia yaitu Chromodoris lineolata, Phyllidiella nigra, Thuridilla lineolata dan Thuridilla sp. serta pada daerah karang batu ditemukan 5 jenis Nudibranchia yaitu Chromodoris lineolata, Phyllidia varicosa, Phyllidiella nigra, Thuridilla lineolata, Thuridilla sp. Pada daerah karang bercabang paling banyak ditemukan Nudibranchia jenis Thuridilla lineolata 16 ind $/ 300 \mathrm{~m}^{2}$. Pada daerah karang batu ditemukan paling banyak jenis Chromodoris lineolata 14 ind $/ 300 \mathrm{~m}^{2}$ dan paling sedikit jenis Thuridilla sp. 7 ind $/ 300 \mathrm{~m}^{2}$. Menurut Goodfrey (2001), Chromodoris merupakan salah satu organisme diurnal, sehingga dengan waktu penelitian pada siang hari maka Chromodoris dapat ditemukan. Chromodoris merupakan genus yang distribusinya sangat kosmopolitan dan keanekaragamannya paling baik di wilayah tropis (Gosliner dan Draheim, 1996).

Penutupan substrat perairan dimasing-masing lokasi paling besar tertutupi oleh karang hidup yaitu pada daerah karang bercabang bernilai $64,48 \%$ dengan jumlah Nudibranchia sebanyak 38 ind $/ 300 \mathrm{~m}^{2}$ dan pada daerah karang batu sebesar $75,87 \%$ dengan jumlah Nudibranchia 50 ind $/ 300 \mathrm{~m}^{2}$. Godfrey (2001) dalam penelitiannya menyebutkan bahwa hewan Nudibranchia lebih banyak berkumpul di tempat yang kondisi tutupan terumbu karangnya baik dibandingkan dengan tutupan karang rusak. Peningkatan tutupan terumbu karang diikuti peningkatan kelimpahan, kekayaan spesies dan keanekaragaman.

Berdasarkan gambar 1, Nudibranchia didapatkan pada substrat karang hidup, karang mati dan pecahan karang. Semua jenis Nudibranchia berada pada substrat karang hidup dan karang mati. Terdapat beberapa Nudibranchia yang hanya terdapat pada pecahan karang, yaitu Thuridilla lineolata 4 individu dan Phyllidiella nigra dengan jumlah 11 individu. Hal ini disebabkan bahwa di lokasi penelitian terdapat rubble (pecahan karang) beralga. Famili Phyllidiidae merupakan salah satu spesies Nudibranchia yang umum dijumpai di daerah tropis dan di wilayah Indo- Pacific dan melimpah saat siang hari (Brunckhorst, 1993). Menurut Godfrey (2001), Faktor yang mempengaruhi kelimpahan Nudibranchia dalam habitatnya adalah kondisi baik buruknya persentase penutupan terumbu karang, ketersediaan dan jenis makanan. Terumbu karang yang baik akan mempunyai tutupan karang lebih dari 30\% (gabungan antara karang keras dan karang lunak) dan penutupan patahan (rubble), batuan dan pasir yang rendah

\section{Indeks Keanekaragaman Terumbu Karang dan Nudibranchia}

Hasil analisa yang didapatkan untuk indeks keanekaragaman $\left(\mathrm{H}^{\prime}\right)$ terumbu karang daerah karang bercabang sebesar 2,475 dan pada daerah karang batu sebesar 2,4745. Berdasarkan pada indeks keanekaragaman tersebut menunjukkan bahwa nilai keanekaragaman terumbu karang tinggi dan sangat stabil. Nilai indeks keseragaman karang di rataan terumbu karang pada daerah karang bercabang yaitu 0,893 dan pada daerah karang batu sebesar 0,840. Indeks keseragaman mendekati angka 1 yang berarti bahwa dalam komunitas tersebut tidak didominasi oleh satu spesies tertentu dan ekosistem dalam kondisi relatif baik. Tutupan terumbu karang dapat mempengaruhi keanekaragaman Nudibranchia karena terumbu karang yang baik dapat menghasilkan makanan dan nutrisi yang dibutuhkan bagi ikan dan hewan moluska khususnya Nudibranchia (Godfrey, 2001).

Indeks keanekaragaman (H') Nudibranchia pada daerah karang bercabang yaitu sebesar 1,315 dan pada daerah karang batu memiliki nilai $\mathrm{H}^{\prime}$ sebesar 1,582. Hal ini menunjukkan bahwa nilai indeks keanekaragaman nudibranchia dalam kisaran sedang. Nilai indeks keseragaman Nudiranchia pada karang bercabang sebesar 0,949 dan pada karang batu sebesar 0,983 . Nilai indeks keseragaman nudibranchia pada kondisi relatif baik, yaitu mendekati angka 1. Bell dan Galzin (1984) menyebutkan dalam penelitiannya bahwa, terdapat hubungan langsung antara tutupan karang hidup dan keanekaragaman spesies organisme bentik. Diduga bahwa ditempat dimana tutupan karang baik, maka makin banyak jumlah Nudibranchia dan makin baik keanekaragaman spesiesnya. 


\section{Kelimpahan Nudibranchia pada Daerah Karang Bercabang dan Daerah Karang Batu}

Rata-rata kelimpahan Nudibranchia pada karang batu sebesar 4,800 dan pada karang bercabang sebesar 2,600. Pada Uji Independent T-Test dengan taraf signifikasi 5\% dimana F hitung Levene's sebesar 3,66 dengan probabilitas signifikasi $(0,092)>0,05$, maka $\mathrm{H}_{0}$ diterima atau memiliki varians kelimpahan yang sama. Pada equal variance assumed didapatkan t hitung sebesar 0,371. Jadi dapat disimpulkan bahwa ratarata kelimpahan Nudibranchia pada karang bercabang dan batu adalah tidak berbeda secara signifikan. Hal ini membuktikan bahwa kelimpahan Nudibranchia sangat dipengaruhi oleh adanya terumbu karang dan tidak berbeda antara karang bercabang dan karang batu.

\section{Parameter Perairan pada Lokasi Penelitian}

Berdasarkan tabel 9, parameter perairan, suhu berkisar antara $29-32^{\circ} \mathrm{C}$. Suhu tersebut dapat mendukung pertumbuhan dan kehupan karang serta biota yang berasosiasi dengan terumbu karang. Menurut Sukarno (1995), perkembangan terumbu karang dan biota di sekitar karang yang optimal terjadi di perairan yang rata-rata suhunya $25-35^{\circ} \mathrm{C}$.

Salinitas perairan di lokasi penelitian didapatkan nilai seesar 30 sampai $34 \%$. Kisaran ini masih sesuai untuk pertumbuhan dan perkembangan terumbu karang. Terumbu karang dapat tumbuh dan berkembang pada kisaran salinitas antara 30 sampai $36 \%$ (Nybakken, 1992). Nilai pH pada lokasi penelitian yaitu 8 yang berarti normal. Menurut Supriharyono (2007), pH yang menunjang bagi kehidupan karang berkisar antara 6,5 hingga 8,5. Kisaran kedalaman pada lokasi penelitian yaitu kurang dari 25 meter. Nybakken (1992) menyatakan bahwa terumbu karang tidak dapat berkembang di perairan yang lebih dalam dari 50 - 70 meter. Kebanyakan terumbu karang tumbuh di kedalaman 25 meter atau kurang.

Kecerahan perairan pada di lokasi penelitian yaitu masih terlihat sampai dasar perairan. Kecerahan berhubungan dengan penetrasi cahaya. Faktor ini sangat berhubungan dengan ketersediaan cahaya dan tingkat kecerahan perairan. Menurut Sukarno (1995), terumbu karang tidak dapat tumbuh dan berkembang pada kedalaman perairan lebih dari 50 meter. Pertumbuhan karang dan biota yang berasosiasi dibatasi oleh kedalaman yang yang berhubungan dengan penetrasi cahaya matahari yang masuk dalam perairan.

\section{KESIMPULAN DAN SARAN \\ Kesimpulan}

Kesimpulan yang diperoleh dari penelitian adalah:

1. Terdapat 5 jenis Nudibranchia pada lokasi penelitian. Pada daerah karang bercabang (lokasi A), jumlah kelimpahan Nudibranchia yaitu sebanyak 38 ind $/ 300 \mathrm{~m}^{2}$ Nudibranchia dan pada lokasi karang batu adalah 50 ind $/ 300 \mathrm{~m}^{2}$ Nudibranchia.

2. Rata-rata kelimpahan Nudibranchia pada karang bercabang dan batu adalah tidak berbeda secara signifikan. Hal ini membuktikan bahwa kelimpahan Nudibranchia sangat dipengaruhi oleh adanya terumbu karang dan tidak berbeda antara karang bercabang (branching) dan karang batu (massive).

\section{Saran}

Saran yang dapat diberikan adalah:

1. Diperlukan pengawasan terhadap kelestarian ekosistem terumbu karang sebagai habitat Nudiranchia dan biota lainnya agar tetap lestari.

2. Perlu adanya penelitian lanjutan yang berhubungang dengan Nudibranchia agar lebih banyak informasi dan pengetahuan yang didapat khususnya di Perairan Kepulauan Karimunjawa.

\section{DAFTAR PUSTAKA}

Allen, G.R. dan Steene, R. 1994. Indopacific Coral Reef. Field Guide. Published by Tropical Reef Research. Singapore.

Azhar, I. dan E. N. Edinger. 1996. Ekotipologi Terumbu Karang pada Perairan P. Cemara Kecil, P. Menyawakan dan Gosong Cemara, Taman Nasional Laut Karimunjawa. Sub BKSD Jawa Tengah dan Universitas Diponegoro-McMaster University Project. Semarang.

Bell, J.D. dan Galzin, R. 1984. Influence of Coral Cover on Coral-Reef Fish Communities. Marine Ecology Progress Series 15: 265-274.

Brunckhorst, D. J. 1993. The Systematics and Phylogeny of Phyllidiid Nudibranchs (Doridoidea)". Records of the Australian Museum. Supplement 16: 1-107, pls.1-9, ISBN:0 73100065 X.

Dahuri, Rokhmin, J. Rais, S.P. Ginting, dan M.J. Sitepu. 2001. Pengelolaan Sumberdaya Wilayah Pesisir dan Lautan Secara Terpadu. PT. Pradnya Paramita. Jakarta.

English, S., Wilkinson, C., Baker,V,. 1994. Survey Manual For Tropical Marine Resources. ASEAN Australia Marine Science Project Living Coastal Resources. Australia. 
Godfrey, S. 2001. Factors Affecting Nudibranch Diversity in The Wakatobi Marine National Park,URLhttp://www.opwall.com/../Invertebrates/Godfrey,\%20S\%20Factors\%20affecting\%20nudibr nch\%20distribution.pdf>. Diakses pada tanggal 21 Februari.

Gosliner, T.M. dan Draheim, R. 1996. 'Indo Pacific Opisthobranch Gastropod Biogeography: How Do We Know What We Don't Know?”. Am. Malacol. Bull. 12, 37-43.

Hadi, S. 1980. Metodologi Research. ANDI. Yogyakarta

Keputusan Mentri Lingkungan Hidup No. 4 Tahun 2001 tentang Pedoman Pengukuran Kondisi Terumbu Karang. Jakarta

Nybakken, J. W. 1992. Biologi Laut: Suatu Pendekatan Ekologis. PT. Gramedia. Jakarta.

Samingan, T. 1993. Dasar-Dasar Ekologi. Universitas Gajahmada. Yogyakarta

Sukarno, R. 1995. Ekosistem Terumbu Karang dan Masalah Pengelolaannya. Materi Pendidikan dan Pelatihan Metodologi Penelitian Penentuan Kondisi Terumbu Karang. Pusat Penelitian dan Pengembangan Oseanologi LIPI dan Universitas Diponegoro. Semarang.

Supriharyono. 2007. Pengelolaan Ekosistem Terumbu Karang. Penerbit Djambatan. Jakarta.

Wibisono, M. S. 2005. Pengantar Ilmu Kelautan. PT. Gramedia Widiasarana Indonesia, Jakarta 